\title{
SUBFOSSIL TREE DEPOSITS IN THE MIDDLE DURANCE (SOUTHERN ALPS, FRANCE): ENVIRONMENTAL CHANGES FROM ALLERØD TO ATLANTIC
}

\author{
$\mathrm{C}_{\text {Miramont }}{ }^{1} \bullet \mathrm{O} \mathrm{Sivan}^{1} \bullet \mathrm{T}^{\text {Tosique }}{ }^{2} \cdot \mathrm{JL}_{\text {Edouard }}{ }^{1} \bullet \mathrm{M} \mathrm{Jorda}^{3}$
}

ABSTRACT. The purpose of this paper is to analyze the numerous holocene subfossil trees (Pinus silvestris) buried in alluvial deposits in the Southern French Alps. These trees lived between the Allerød and Subboreal periods, according to ${ }^{14} \mathrm{C}$ dates. Our dendochronological studies explain the trees' sudden death as due to morphological crisis brought on by climatic oscillations. Tree-ring series could be used to identify the variability of early Holocene atmospheric ${ }^{14} \mathrm{C}$ levels.

\section{INTRODUCTION}

In the Middle Durance region (Southern Alps, France; Figure 1A), numerous groups of subfossil trees (pinus silvestris) are buried in alluvial and colluvial deposits. The trees, which are remarkably well preserved, have been radiocarbon dated between the Allerød and the Subboreal periods (Archambault 1967, 1968, 1969; Delibrias et al. 1984; Gautier 1992; Rosique 1994, 1996; Miramont 1998; Sivan 1999). These trees, which have not been extensively studied to date, have the potential to reveal much about the paleoenvironments-paleoclimate, geomorphology, paleoecology — of the first part of the Postglacial period. The goals of this article are: 1) to inventory the deposits of subfossil trees known to exist in the southern French Alps, and 2) to present the first results of the dendrogeomorphologic study of the trees in the Saignon and Charanc basins.

The middle Durance basin is an area with mountains ranging in altitude from 500 to $2000 \mathrm{~m}$. It is influenced by both Mediterranean and mountain climates. The region is dominated by an outcrop of calcareous marl, notably from the superior Jurrasic ("terres noires"). As these structures exist on steep slopes highly susceptible to erosion, they are particularly sensitive to paleoenvironmental changes. Therefore, climatic changes since the Late Glacial period are well recorded in alluvial fillings.

Figure 1B and Table 1 show all of the known Holocene subfossil tree sites in the Southern Alps, as well as their ${ }^{14} \mathrm{C}$ dates. The subfossil trees are found in distinct geographical areas. The Buëch basin has been studied the most and has the most known tree sites. The tributaries of the Sasse, Bléone, and Ubaye Rivers also reveal important sites. The Charanc, Saignon, Drouzet, and Messires Oddou basins are particularly rich in subfossil tree deposits. In others, only isolated trunks have been discovered. In total, about 30 sites are known, but most of the area has not been investigated, and the region's frequent flash floods and susceptibility to erosion mean that new sites could easily be exposed, or old ones easily reburied or destroyed.

Pinus Silvestris stumps are buried at various depths in alluvial and colluvial fillings from the first part of the postglacial period (Jorda 1980, 1993). The stumps have recently been exposed by the renewed activity of the rivers. Many of the stumps still have pieces of bark. Most of the trees are upright and rooted in lower alluvial layers, which also contain vegetal debris and often charred wood. Other trees are horizontal or broken. The trunks measure up to $60 \mathrm{~cm}$ in diameter and 1-3 $\mathrm{m}$ in height. Some of them are up to 300 years old. These subfossil trees can be distinguished from recent stumps in three ways: their unusual placement in relation to present waterways, their hardness, and their particular odor.

${ }^{1}$ IMEP - UMR 6116 CNRS, case 451, Faculté des Sciences et Techniques de St Jérôme, Avenue Escadrille Niemen, 13397 Marseille Cedex 20, France. Email: mirajor@ aol.com; jean-louis.Edouard@LBHP.u-3mrs.fr.

${ }^{2}$ CEREG - EP 2037 CNRS/ULP/ENGEES, Faculté de Géographie, Université Louis Pasteur, 3 rue de l'Argonne, 67083 Strasbourg Cedex, France. Email: rosique@geographie.u-strasbg.fr.

${ }^{3}$ Institut de Géographie, Université de Provence, Avenue R. Schuman, 13621 Aix en Provence, France 


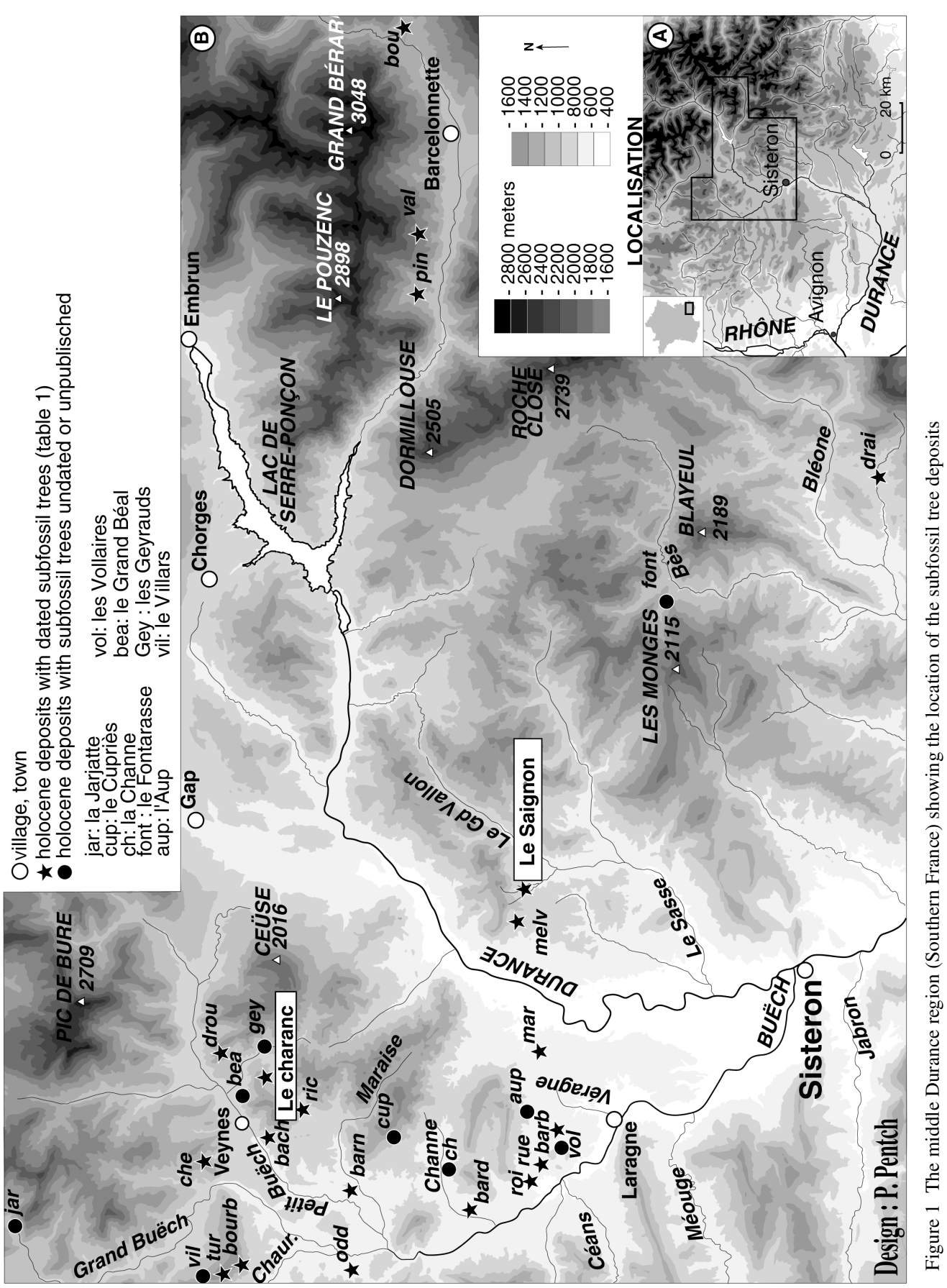




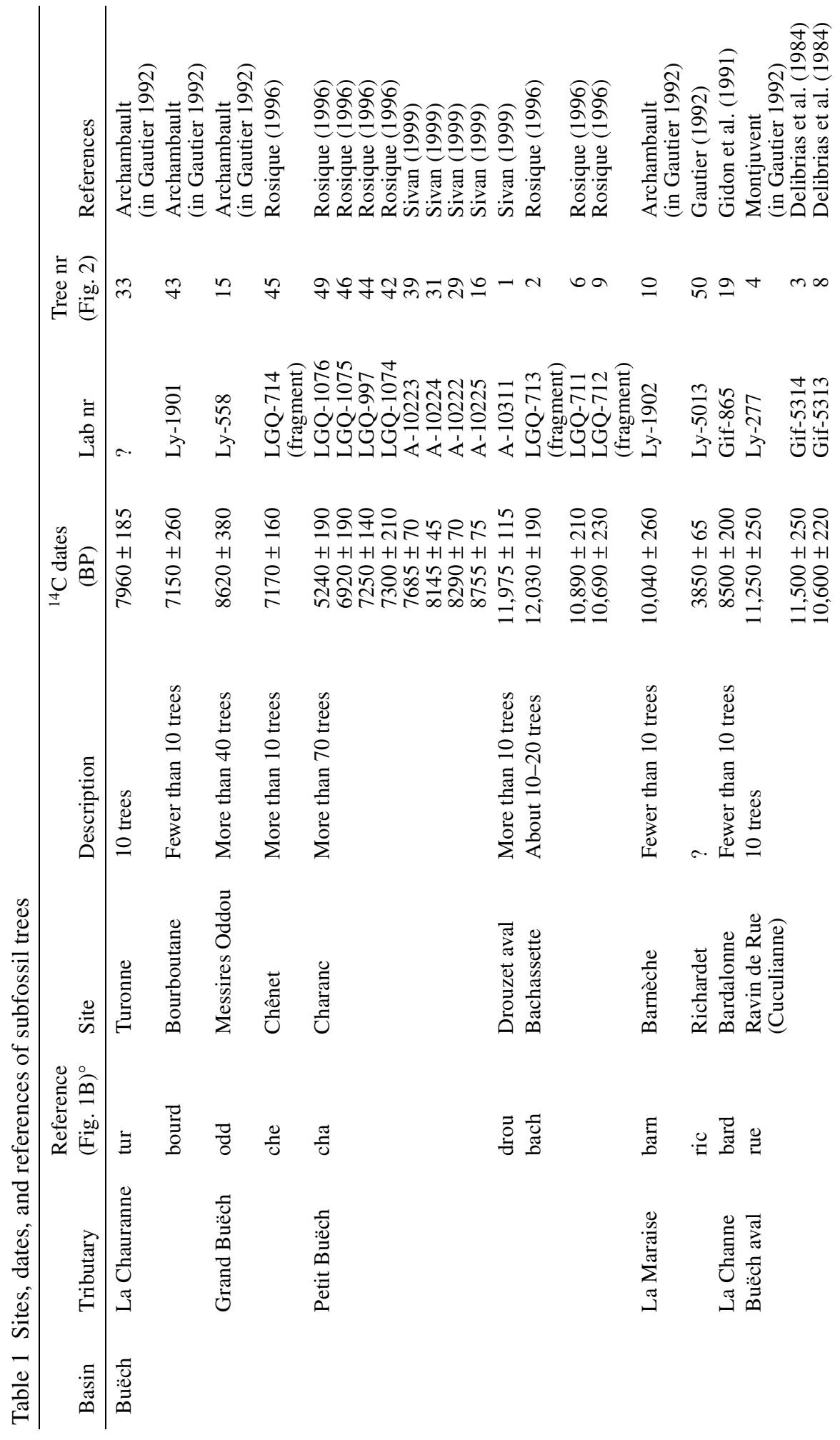




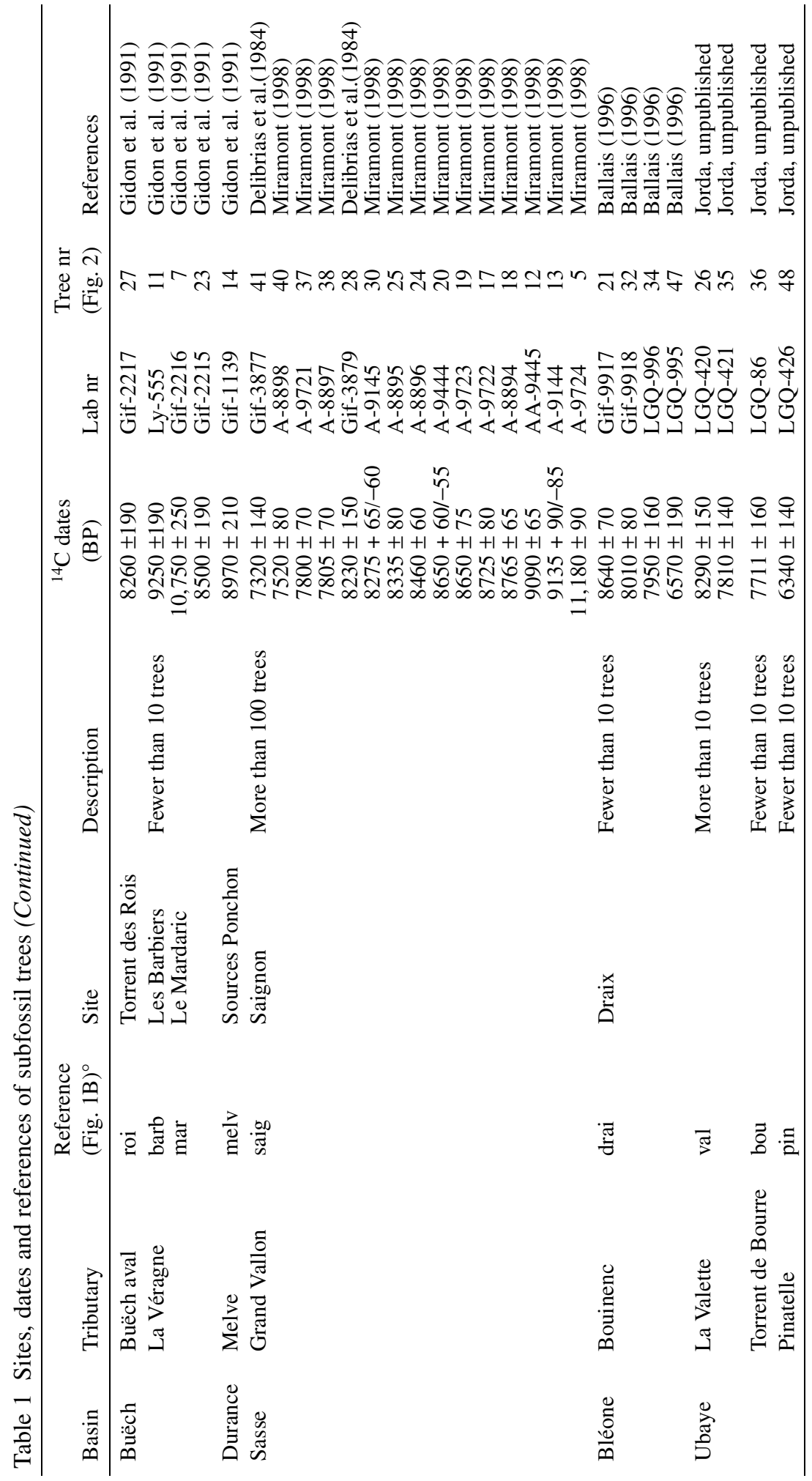




\section{RESULTS}

An overview of the ${ }^{14} \mathrm{C}$ dates of the trees is shown in Figure 2. The trees are compared with the morphogenetic evolution of the river beds in which they were found, as described by Borel et al. (1984), Jorda (1980, 1985, 1993), Jorda and Rosique (1994), Rosique (1994, 1996), and Miramont (1998). The morphogenetic activity of the region's waterways during the first part of the late glacial period was characterized by a phase of major vertical incision. From the Allerød until the Atlantic periods, the tendency was sedimentary accumulation. Large embankments were therefore formed-some up to $20 \mathrm{~m}$ thick - and alluvial cones were deposited at the base of the slopes, lateral to the principal direction of flow (principal Holocene filling; Jorda 1980, 1993). All of the trees (except nr 2) are buried in these embankments. There are two distinct groups of dates. The first group, consisting of 10 dates, belongs to the second part of the late glacial period; the Allerød and Younger Dryas. The second group, consisting of 39 dates, ranges from the end of the Preboreal to the beginning of the Atlantic period. This division into two groups is explained by a lower rate of sedimentation and a shift to incision during the Preboreal. This trend was obviously unfavorable for further burial of the pines. During the Boreal and the Atlantic, the rate of sedimentation was higher. After the Atlantic, the waterways once again began a period of vertical incision. This was again unfavorable for burial and conservation. Encased in the principal Holocene embankments are alluvial layers that date from the Subboreal and/or the Subatlantic, and in which only a few trees were found (nr 49 and 50 in Figure 2).

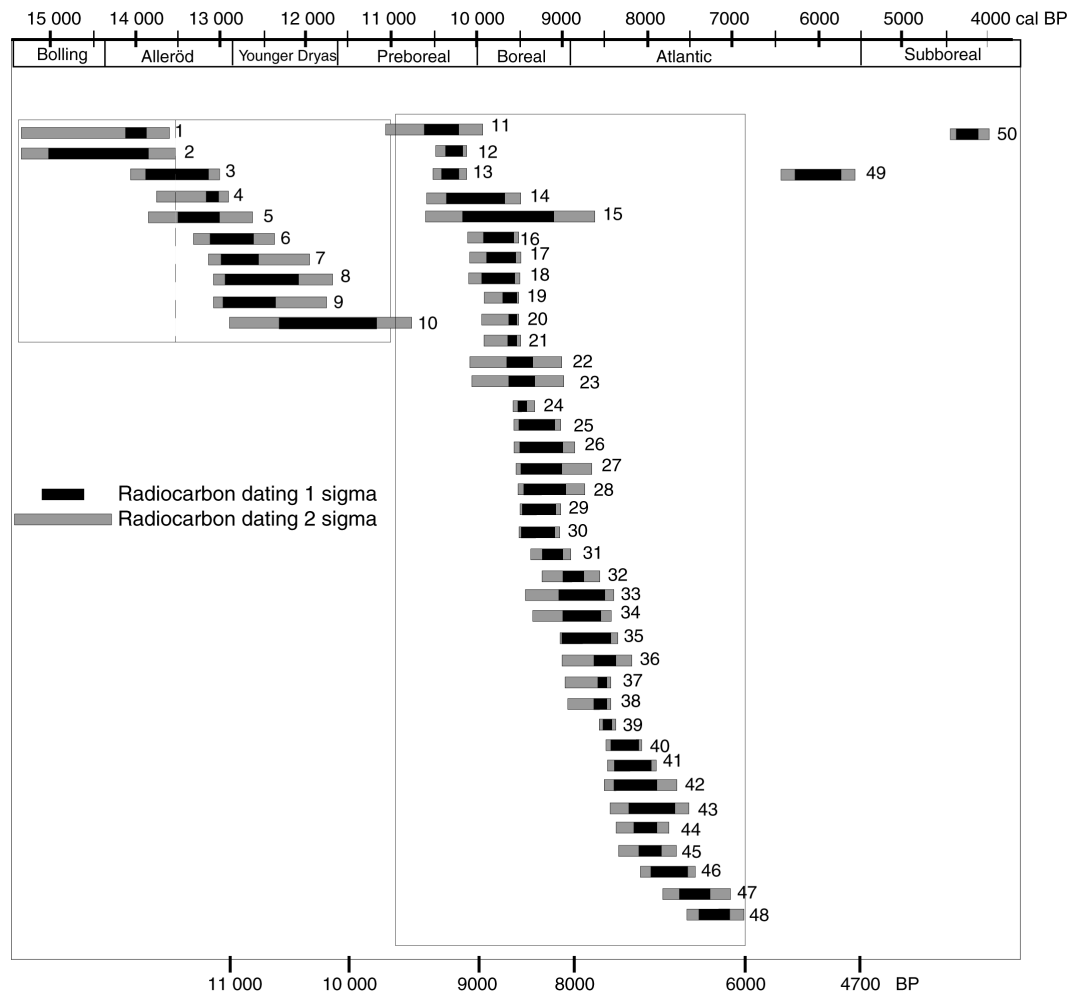

Figure $2{ }^{14} \mathrm{C}$ dates of Holocene subfossil trunks from the middle Durance basin. All the dates are calibrated with INTCAL98 (Stuiver et al. 1998). Most of the trees are buried in alluvial deposits during a time span from Allerød to Atlantic. For location and reference see Table 1 and Figure 1. 
Two particularly important sites have recently been studied: Drouzet (Buëch basin; Rosique 1996; Sivan 1999) and Saignon (Sasse basin; Miramont 1998). These sites will be discussed in detail below.

\section{The Saignon Basin}

The Saignon is a small basin of approximately 400 hectares (ha) within the larger Sasse drainage. It is dominated by calcareous marl ("terres noires"). The alluvial embankments are well developed and contain over 100 subfossil pinus silvestris. The trunks are found both at the bottom of the river beds and in higher strata. Geomorphological analysis of the deposits shows that they were buried by a rapid sequence of floods. This speed of burial explains the wood's remarkable conservation. The subfossil trunks are the remnants of adult forests. They were 100-300 years old.

Most of the trees were sampled for tree-ring analysis, except for some trunks because they were difficult to access, or were too badly preserved, or had fewer than 40 rings. We measured 57 different individual tree chronologies. Fifteen ${ }^{14} \mathrm{C}$ dates were obtained (two of which are from previous studies [Delibrias et al. 1984]): they range from the Allerød to the Atlantic. These ${ }^{14} \mathrm{C}$ dates and the geomorphological analysis of the site (stratigraphic analysis, proximity of rooted trees) permitted the identification of four distinct groups of sub-contemporaneus rooted trees (80 trees are included in these four groups, 20 trees cannot be associated with one of them). In these groups, 47 individual tree chronologies were computed. Synchronization reveals three distinct average chronologies comprising 34 of the 47 individual tree chronologies. These average chronologies, as well as typical growth curves are shown in Figure 3; the four groups are shown in Figure 4.

Group 1 includes at least two trees. ${ }^{14} \mathrm{C}$ dating gave an age of 11,180 $\pm 90 \mathrm{BP}$. Two individual tree chronologies were computed but they cannot be synchronized.

Group 2 includes at least 27 trees. ${ }^{14} \mathrm{C}$ dating gave ages of $9090 \pm 65 \mathrm{BP}$ and $9135 \pm 85 \mathrm{BP}$. Thirteen individual tree-ring chronologies were computed, nine of them were synchronized (MC 2; Figure 3).

Group 3 includes at least 34 trees. ${ }^{14} \mathrm{C}$ dating gave the following ages: $8725 \pm 80,8765 \pm 65,8650$ $\pm 75,8650 \pm 55,8460 \pm 60,8335 \pm 80,8275 \pm 65$, and $8230 \pm 65$ BP. Twenty-one individual tree chronologies were computed. Fourteen tree-ring curves were synchronized (MC 3b, Figure 3). Two sub-groups (3A and 3B [Figure 4]) are distinct, wherein the trees belong to different alluvial layers.

Group 4 includes at least 17 trees. ${ }^{14} \mathrm{C}$ dating gave the following ages: $7800 \pm 70,7805 \pm 80,7520$ \pm 80 , and $7320 \pm 140 \mathrm{BP}$. Eleven individual tree chronologies were computed. Eight tree-ring curves were synchronized (MC4; Figure 3).

Two-thirds of the individual chronologies show similar characteristics, namely a rapid reduction in growth, followed by a period with very little growth leading to the death of the trees (Figure 3). This points to rapid changes in the biotope conditions. These changes likely have a causative relation with the burial of the trees and the changing sedimentation of the period. Similar growth anomalies have been observed with subfossil trees smothered by rising water levels (Edouard 1994; Visset et al. 1994; Kaiser 1987; Munaut and Casparie 1971).

\section{The Drouzet Basin}

The Drouzet, a tributary that joins the Petit Buëch on its left bank, runs in a valley carved from Superior Jurassic limestone (marno-calcareous). It is on the northwest side of the Ceüse-Aujour basin. 

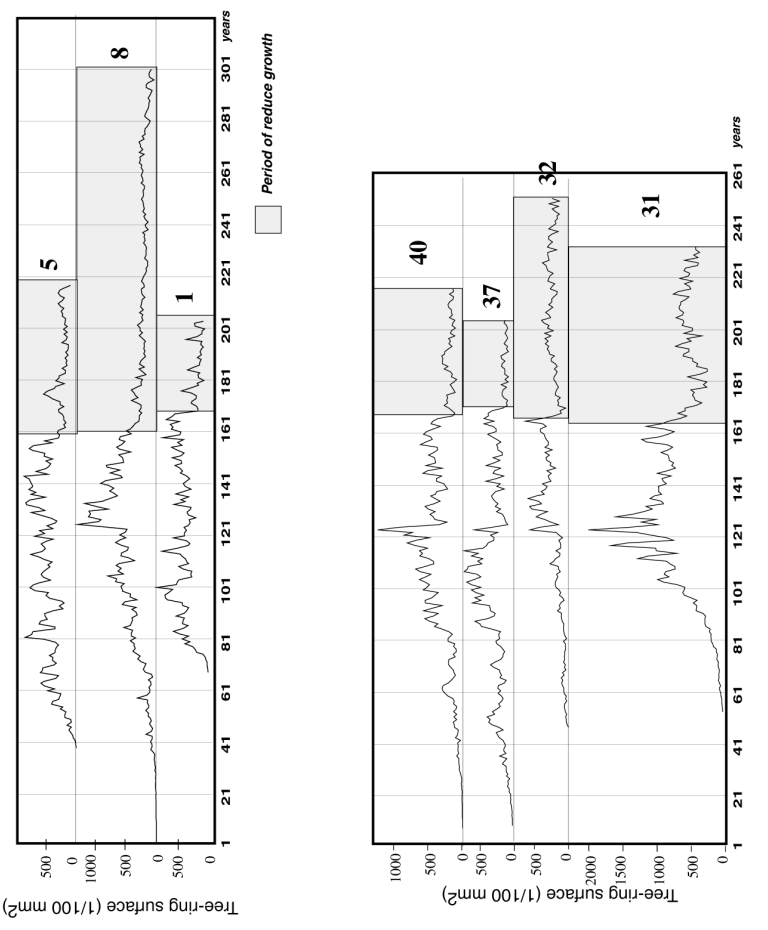

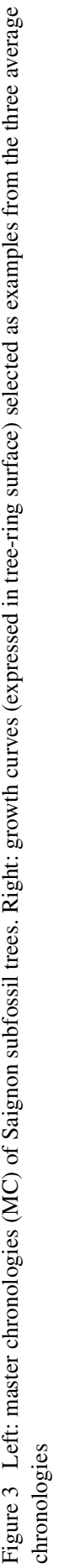



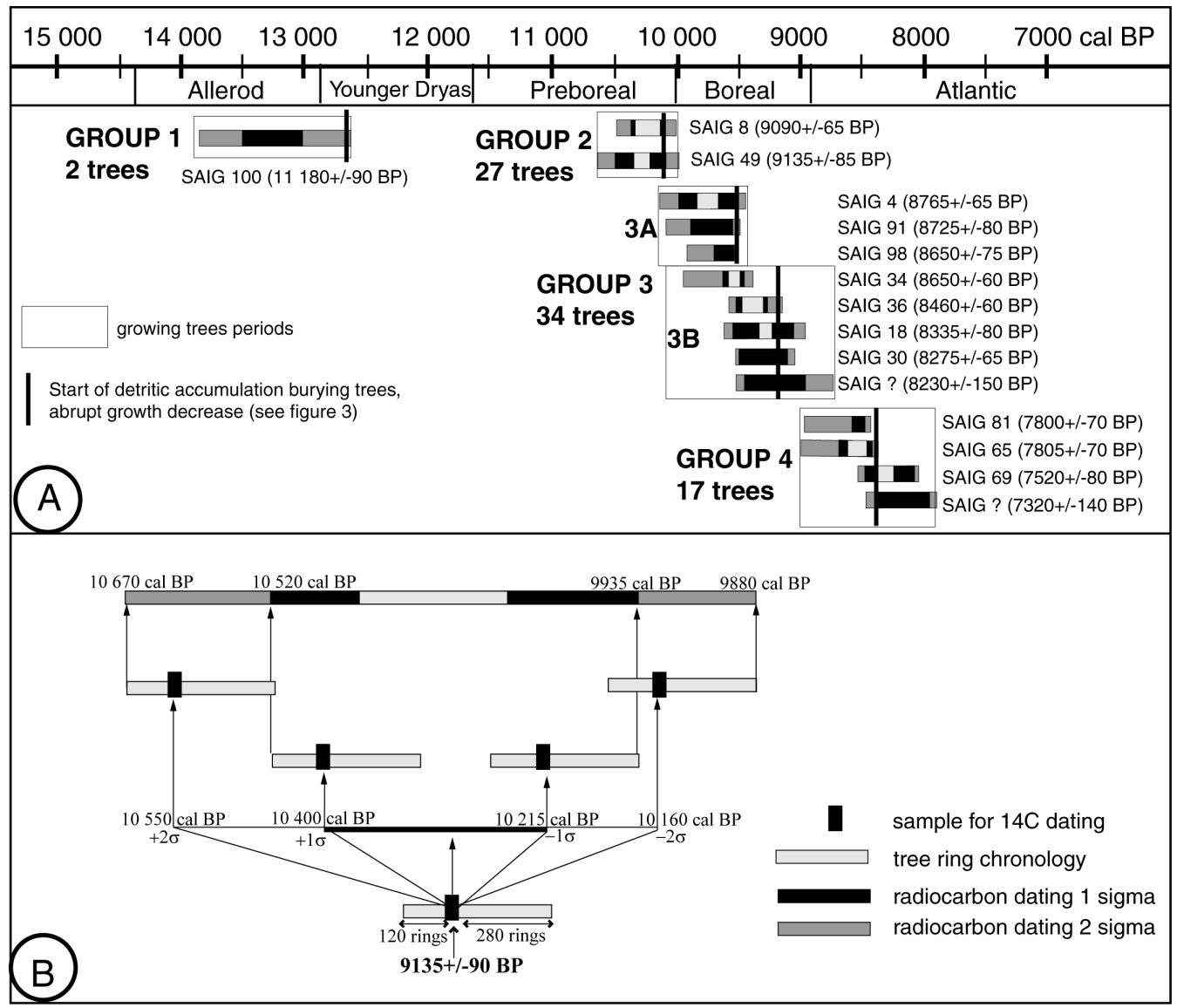

Figure 4 A: ${ }^{14} \mathrm{C}$ dating of Saignon subfossil trunks. Groups are determined by geomorphological and stratigraphic analyses and radiocarbon dates. B: method to represent ${ }^{14} \mathrm{C}$ dates. All the dates are calibrated with INTCAL98 (Stuiver et al. 1998).

Downstream, the river revealed a deposit of some 20 trees buried in a black clay alluvial embankment $10 \mathrm{~m}$ thick. One specimen has been dated from the Allerød (11,975 $\pm 115 \mathrm{BP}$; DROU 3; Figure 5). This is similar to two dates of specimens from tributaries to the Buëch, one from the Rue stream (Delibrias et al. 1984), and one from the Bachassette (Rosique 1996).

Upstream, the Drouzet is fed by the Charanc stream, which drains a small, steep basin of some 20 hectares. Like the Saignon, this basin is carved from Jurassic "black marls".

The deposits which constitute the "principal Holocene filling" form a glacis-terrace perched at a relative height of $20 \mathrm{~m}$ upstream, and $6 \mathrm{~m}$ downstream. More than 50 subfossil trees have been counted there. They are randomly buried in alluvial or gravelly layers. Other trunks are buried in the main embankment. Trees without roots are more frequent than in the Saignon basin. This is probably an indication for a more vigourous morphogenetic activity caused by the steepness of the basin.

The radiocarbon dates place the trees in the Boreal and Atlantic periods. They are almost contemporary to those obtained in the Saignon (Figure 5). Nine individual chronologies, with 20-300 rings, were measured ( 6 in the Charanc and 3 from the lower Drouzet). Some of them (like some from the 


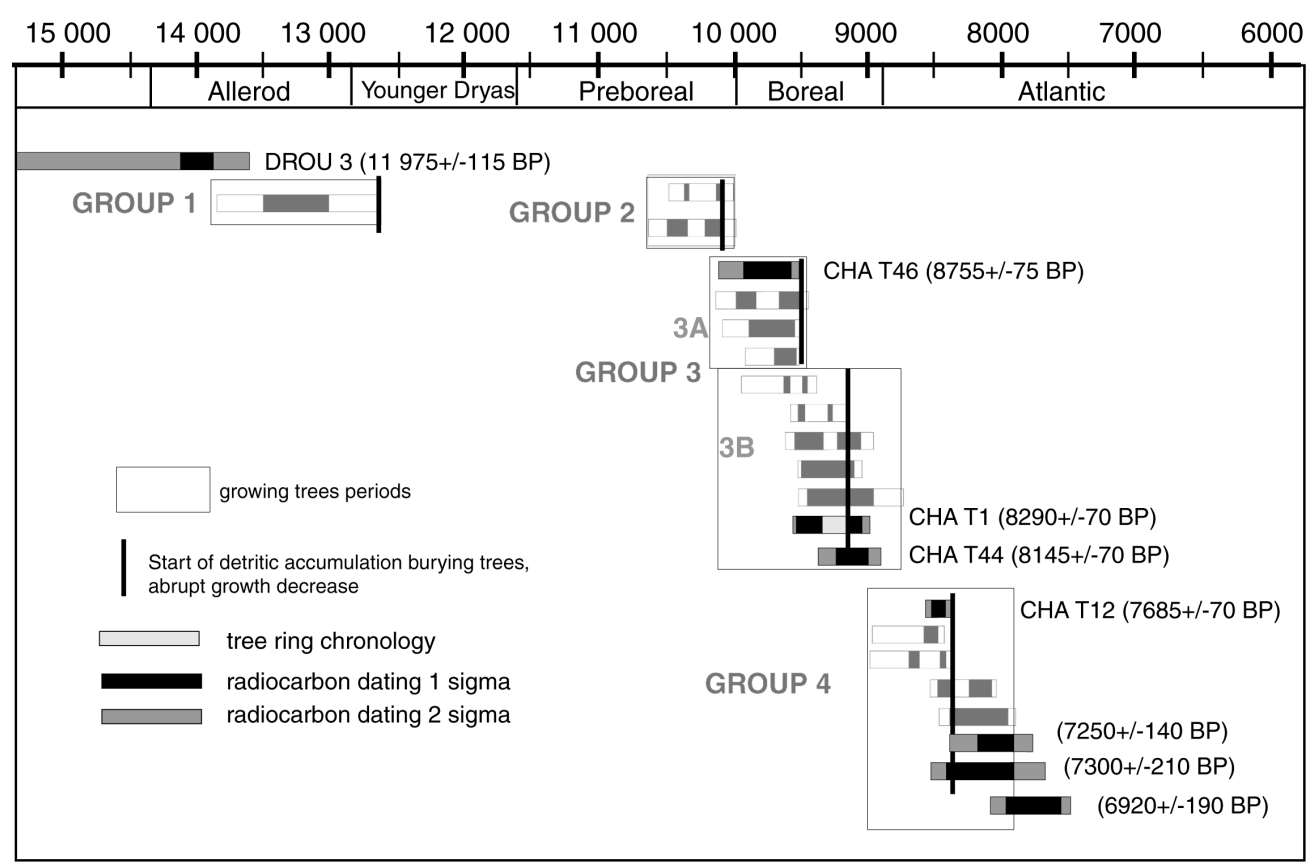

Figure $5{ }^{14} \mathrm{C}$ dates of Drouzet subfossil trunks and Saignon subfossil trunks (in gray). All the dates are calibrated with INTCAL98 (Stuiver et al. 1998). The dates in the Drouzet basin are from the same time interval as those from the Saignon. This suggests that tree growing periods are simultaneous in the two basins.

Saignon basin) reflect important growth anomalies (Figure 6). The others have extremely thin growth rings (sometimes less than $0.5 \mathrm{~mm}$ ) which suggest difficult biotope conditions. Unfortunately, it has not yet been possible to synchronize the ring chronologies from the Charanc with those from the Saignon.

\section{DISCUSSION}

The presence, in the Middle Durance basins, of trees buried in alluvial Holocene layers demonstrates the succession of two types of dynamic morphology between the Allerød and the Atlantic periods. This is illustrated in Figure 7. One type was a period of stability or/and river bed incision which was favorable for the growth of the pine trees. This stability is due to a reduction in the detrital flow as well as more regular hydrous flow. The second type of morphogenesis was a period of floodplain accretion resulting in the accumulation of alluvial deposits. They were responsible for the burial of the pines and likely also explain the growth accidents observed in the ring chronologies.

The dates obtained from the Drouzet and Charanc basins are from the same time interval as those from the Saignon. This contemporaneity suggests a common cause, probably a climatic variation.

The nature of the deposits reveal a seasonal or annual flooding for many centuries. The geomorphological changes in the different basins are commensurate with climatic variations, notably an increase in the frequency and intensity of precipitation. These climatic crises in Haute Provence occurred at the same time as a general increase in humidity in Basse Provence (Bruneton et al. 2000). These results fit well with recent hypotheses on the paleoclimatic evolution of the first part of the Holocene (Alley et al. 1997; Magny 1995, 1997). This interpretation still has to be confirmed by further study of subfossil tree sites in the Middle Durance region. 

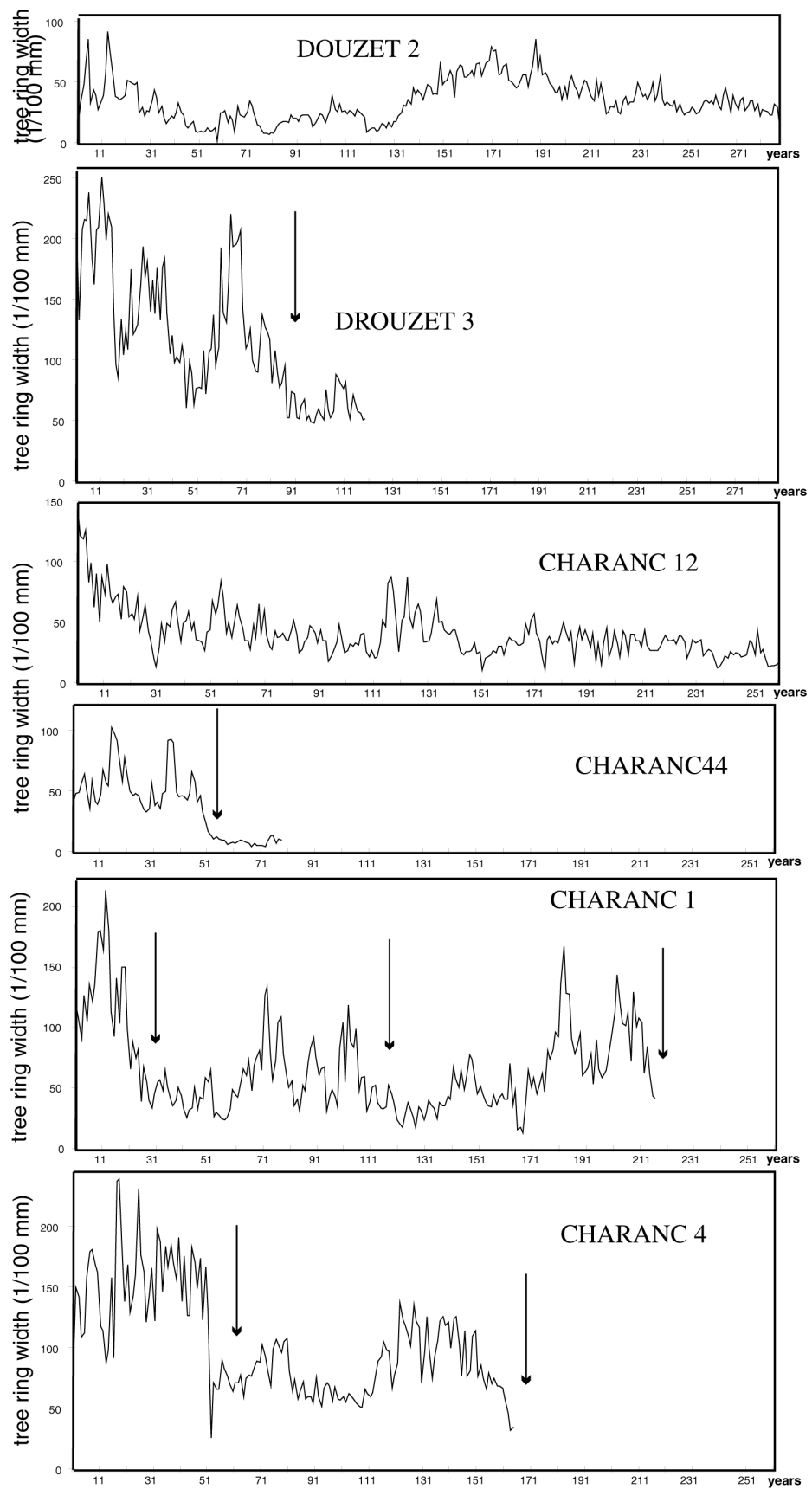

Figure 6 Examples of tree-ring curves of Drouzet basin. An abrupt decrease in growth is observed, as in the Saignon basin, due to accumulation of alluvial deposits. 


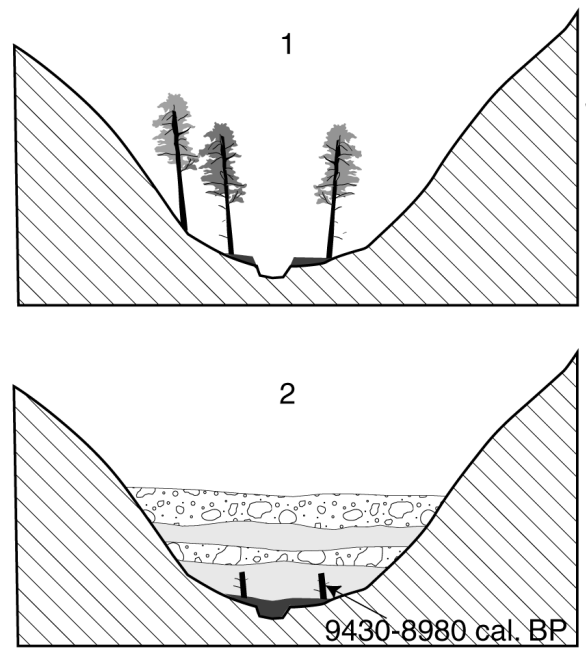

BOREAL

Scots pines are growing

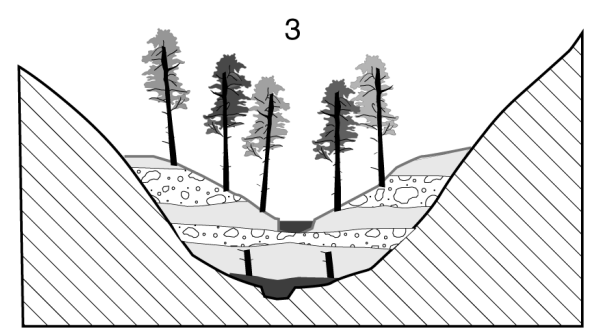

ATLANTIC

BOREAL

Scots Pines are buried

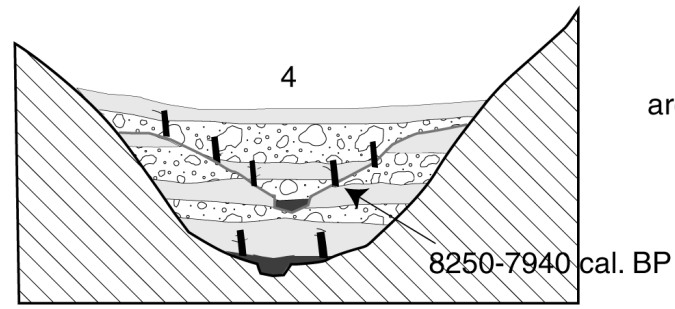

ATLANTIC

The pines are buried again

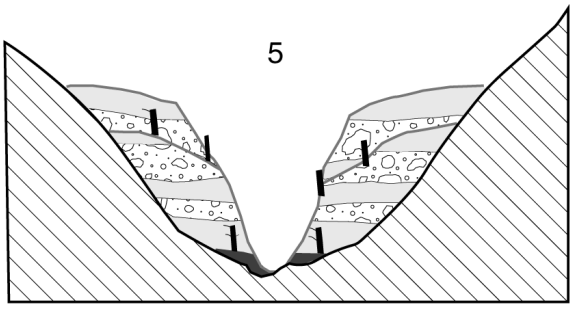

TODAY

The pines are revelead by incision

silty deposits $\square$ sandy deposits 0.00 .0 coarse deposits jurassic marls

Figure 7 Schematic view, showing geomorphological changes in the Saignon valley 
These tree deposits have important potential in terms of the study of paleoenvironments and especially in terms of the eventual possibility of obtaining good average chronologies for the Allerød and the Younger Dryas, for which there are only a few known subfossil trees (Becker 1993; Stuiver et al. 1998). The dendochronological analysis of these trees could permit the extension of the calibration curve of the ${ }^{14} \mathrm{C}$ scale.

In addition, the Middle Durance floating chronologies, due to their annual resolution, can provide high resolution information about temporal changes in atmospheric ${ }^{14} \mathrm{C}$ levels (Kromer et al. 1998), notably for the study of "the wiggles" during the end of the Late Glacial. This raises the question of the relation between the ${ }^{14} \mathrm{C}$ variations and the climatic fluctuations experienced by the trees. The burial level of the trees permits the sedimentary and erosive events caused by climatic fluctuations to be dated, enabling the correlation with the atmospheric ${ }^{14} \mathrm{C}$ levels as recorded in the wood.

\section{CONCLUSION}

The Middle Durance (Southern Alps, France) basin contains many subfossil tree deposits that supply floating chronologies dated between the Allerød and the Atlantic. The dendrogeomorphological study of the sites permits us to relate the morphogenic crises of the region with episodes of inclement weather. More even than their present significance, we would like to point out the potential that these sites have. We hope, as Kromer et al. (1998), that these sections, combined with others, will ultimately help in the reconstruction of the Late Glacial and early Holocene ${ }^{14} \mathrm{C}$ pattern.

\section{ACKNOWLEDGMENTS}

We are grateful to $\mathbf{J}$ van der Plicht and $\mathbf{J}$ Evin for information and advice. We also express thanks to D Ronah for translation and to P Pench for design. This work was financed by the Region and the Réserve Géologique de Haute Provence.

\section{REFERENCES}

Alley RB, Mayewski PA, Sowers T, Stuiver M, Taylor KC, Clark PU. 1997. Holocene climatic instabilitya prominent widespride event $8200 \mathrm{yr}$ ago. Geology 25:483-6.

Archambault M. 1967. Découverte des restes d'une formation forestière fossile entre deux nappes colluviales quaternaires. Comptes Rendus de l'Académie des Sciences 265:104-7.

Archambault M. 1968. Recensement provisoire des arbres et des formations forestières fossiles du bassin de la Moyenne Durance (Hautes Alpes). Comptes Rendus de l'Académie des Sciences 267:101-2104, 2284-7.

Archambault M. 1969. Faits et points de vue nouveaux sur les glacis d'érosion (exemple du bassin de la Moyenne Durance alpestre). Bulletin de l'Association de Géographes Français 375/376:525-37.

Ballais JL. 1996. L'âge de modelé de roubines dans les Préalpes du Sud: l'exemple de la région de Digne. Géomorphologie: Relief, Processus et Environment 4: 61-8.

Becker B. 1993. An 11,000-year German oak and pine dendrochronology for radiocarbon calibration. Radiocarbon 35(1):201-13.

Borel JL, Jorda M, Montjument G. 1984. Variations cli- matiques, morphogénèse et évolution de la végétation post-würmiennes dans les Alpes françaises. Les Alpes, 25 e Congrès International de Géographie, Paris. $\mathrm{p}$ 43-53.

Bruneton H, Miramont C, Andrieu V. 2000. Dynamique de milieux méditerranéens (bassin du Saignon, Alpes du Sud, marais des Baux, Basse Provence) au cours du Mésolithique: un enregistrement morphosédimentaire des rythmes climatiques. In: Epipaléolithique et Mésolithique: les derniers chasseurs-cueilleurs d'Europe occidentale. Actes du Colloque international, Besançon, Octobre 1998. Paris: Les Belles Lettres. Annales de l'universile de Franche Comté, PUFC, 70-82.

Delibrias G, Gabert J, Jorda M, 1984. Données nouvelles sur la chronostratigraphie et l'évolution paléomorphologique postglaciaire des Alpes du Sud (Moyenne Durance). Comptes Rendus de l'Académie des Sciences 299 (II):263-6.

Edouard JL. 1994. Les lacs d'altitude dans les Alpes françaises. Contribution à la connaissance des lacs d'altitude et à l'histoire des milieux montagnards depuis la fin du Tardiglaciaire. Thèse de Doctorat de Géographie, Université Joseph Fourier, Grenoble I. $795 \mathrm{p}$. 
Gautier E. 1992. Recherches sur la morphologie et la dynamique fluviales dans le bassin du Buech (Alpes du Sud). Thèse de géographie, Université de Paris-XNanterre. 439 p.

Gidon M, Montjuvent G, Flandrin J, Moullade M, Durozoy G, Damiani L. 1991. Notice explicative de la carte géologique de la France au 1/50000, feuille de Laragne-Montéglin (893). BRGM, Orléans. 84 p.

Jorda M. 1980. Morphogenèse et évolution des paysages dans les Alpes de Haute-Provence depuis le Tardiglaciaire. Facteurs naturels et facteurs anthropiques. Bulletin de l'Association de Géographes Français 472: 295-304.

Jorda M. 1985. La torrentialité holocène des Alpes françaises du sud. Facteurs anthropiques et paramètres naturels de son évolution. Symposium International: les modifications de l'environnement dans le bassin méditerranéen occidental à la fin du Pléistocène et pendant l'Holocène. Toulouse. Cahiers Ligures de la Préhistoire, H.S. 2:49-70.

Jorda M. 1993. Histoire des paléoenvironnements tardiet post-glaciaires de moyenne altitude. Essai de reconstitution cinématique. Géomorphologie et aménagement de la montagne, Hommage à P. Gabert. Caen: CNRS. p 91-111.

Jorda M, Rosique T. 1994. Le Tardiglaciaire des Alpes françaises du Sud. Rythmes et modalités des changements bio-morphoclimatiques. Bulletin de l'Association Française pour l'Etude du Quaternaire 3/4:141-9.

Kaiser NFJ. 1987. Late Glacial reforestation in the Swiss Mitteland and in Wisconsin illustrated by the Daettnau and the Two Creeks buried forests. Proceedings of the International Symposium on Ecological Aspects of Tree-Ring Analysis. New-York, 17-21 August 1986. p 291-7.

Kromer B, Spurk M, Remmele S, Barbetti M, Toniello V. 1998. Segments of atmospheric ${ }^{14} \mathrm{C}$ change as derived from late glacial and early holocene floating tree-ring series. Radiocarbon 40(1):351-8.
Magny M. 1995. Une histoire du climat. Des derniers mammouths au siècle de l'automobile. Paris: Errance. $175 \mathrm{p}$.

Magny M. 1997. Eléments pour une histoire du climat entre 13000 et 6000 BP. Bulletin de la société préhistorique française 94(2):161-7.

Miramont C. 1998. Morphogenèse, activité érosive et détritisme alluvial holocènes dans le bassin de la Moyenne Durance. Thèse de Géographie, Université d'Aix-Marseille I. 287 p.

Munaut AV, Casparie WA. 1971. Etude dendrochronologique des Pinus silvestris subfossiles provenant de la tourbière d'Emmen (Drenthe, Pays-bas). Revue Paléobotanique et Palynologie 11:201-26.

Rosique T. 1994. Les gisements de bois fossiles conservés dans les formations détritiques tardi- et postglaciaires du bassin du Buëch (Hautes Alpes): interprétation géodynamique et paléoécologique. Comptes Rendus de l'Académie des Sciences 319(II):373-80.

Rosique T. 1996. Morphogenèse et évolution des paléoenvironnements alpins de la fin des temps glaciaires au début de l'Holocène: l'exemple de la Moyenne Durance (Alpes françaises du Sud). Thèse de doctorat de Géographie, Université d'Aix-Marseille I. 288 p.

Sivan O. 1999. Etude morphosédimentaire et dendrogéomorphologique des remblaiements holocènes à troncs subfossiles. Exemple de la région de Veynes (vallée du Buëch). Mémoire de D.E.A. de Géographie. Université d'Aix-Marseille I. 102 p.

Stuiver M, Reimer PJ, Bard E, Beck JW, Burr GS, Hughen KA, Kromer B, McCormac G, van der Plicht J, Spurk M. 1998. INTCAL98 radiocarbon age calibration, 24,000-0 cal BP. Radiocarbon 40(3):104183.

Visset L, Girardclos O, Lambert GN. 1994. La forêt de chênes sur tourbe, à l'île d'Errand, dans les marais de Brière (Massif armoricain, France). Quaternaire 5(2): 69-77. 